\title{
Short-Term of Malathion Intoxication on Lipid Peroxidation, Antioxidant Activity, and down- regulation of pro-Inflammatory Cytokines: Organophosphorus Pesticide Toxicity in Rat Model
}

Mehran Sayadi ( $\square$ mehransayadi62@gmail.com )

Fasa University of Medical Science https://orcid.org/0000-0002-7761-361X

Mohammad Kiani

Fasa University of Medical Science

Hiva Alipanah

Fasa University of Medical Science

Seyed Mohammad Mazloomi

Shiraz University of Medical Sciences

Roghayeh Nejati

Fasa University of Medical Science

Amene Nematollahi

Fasa University of Medical Science

\section{Research Article}

Keywords: Organophosphates, Cholinesterase Inhibitors, agricultural chemicals, oxidative stress, Environmental Exposure

Posted Date: September 7th, 2021

DOI: https://doi.org/10.21203/rs.3.rs-830877/v1

License: (c) (1) This work is licensed under a Creative Commons Attribution 4.0 International License. Read Full License 


\section{Abstract}

Malathion (MAL), a kind of organophosphate pesticides (OPs), is one of the oldest phosphoric pesticides, which used for both domestic and commercial agricultural purposes. However, it possesses adverse effects and organ-specific toxicity in relation to the heart, kidney and other vertebrate organs. The exact effects of the short-term toxicity of MAL on lipid peroxidation, antioxidant activity, and pro-inflammatory cytokines is not yet clear enough. We evaluated lipid peroxidation (MDA level), antioxidant activity [superoxide dismutase (SOD) and catalase (CAT)], TNF-alpha, and IL-1 bet in different tissues of MALtreated Wistar rats, at doses of 50,100, 200 and $150 \mathrm{mg} / \mathrm{kg}$. After 14 days exposure, CAT and SOD activity, MDA level increased in most tissues. The histopathological results showed that the most sensitive tissues to MAL toxicity were liver, kidney, and heart. Also, in general, increased TNF-alpha measured as inflammatory cytokine compared to untreated rats. IL-1 beta levels showed a dual response to the toxic effects of MAL; increased in testis, kidney and lung tissues and decreased in liver, heart and blood tissues. The present findings reinforce the concept that short-term MAL toxicity can cause tissue damage while enhancing the activity of antioxidant enzymes and reducing cytokine levels.

\section{Introduction}

Pesticides are widely used worldwide to kill or control unwanted pests, and biological organisms in the agricultural industry. In this regard, annually, the use of various pesticides is approximately 2 million tons worldwide, and cause approximately 200000 global deaths, which is expected to increase in the future(Eddleston et al. 2008 ; Heshmati et al. 2020). The use of pesticides is inevitable due to the widespread presence of pests in agricultural products. On the other hand, with the accumulation of these toxins in agricultural products and their entry into the human body, the health of consumers is endangered and lead to acute or chronic side effects and human toxicity(Flehi-Slim et al. 2015; Rahimi et al. 2021). Organophosphorus pesticides (OPs) are one of the most potent pesticides. About 2 to $5 \%$ of OPs reach the target organism and the rest is transmitted to non-target organisms such as animals, plants and the environment(Gupta et al. 2019). OPs have replaced organochlorine pesticides due to faster degradation in the environment and lower persistence(Lasram et al. 2009).

Malathion (MAL) [0,0-dimethyl-S-(1,2-dicarcethoxyethyl) phosphorodithioate], a kind of OPs, is one of the oldest phosphoric pesticides, which is a wide spectrum insecticide, used in public health and residential to kill a variety of insects, as well as for the control of the vectors of diseases (Mostafalou et al. 2012; Jalili et al. 2019). MAL is a lipophilic compound that can easily interact with cell membranes and destroy the phospholipid bilayer structure (Possamai et al. 2007). Furthermore, MAL can cause DNA damage, lipid peroxidation (LPO), enzyme inactivation and oxidative stress (Possamai et al. 2007). In developing countries, however, MAL also causes poisoning-induced deaths.

Previous studies have examined different times and doses of MAL, however, for the first time in our study, the short-term toxicity of MAL on histopathological disorders, lipid peroxidation, antioxidant activity, and pro-inflammatory cytokines in the rat model is investigated. 


\section{Material And Method \\ 2.1. Reagents}

MAL was purchased from Semiran Agricultural Pesticides Company (Tehran, Iran). Corn oil was supplied by Sigma Aldrich Co. Other chemical compounds were obtained from reliable companies with analytical grade.

\subsection{Experimental design}

Thirty-two male Sprague-Dawley rats (250-300 g) were purchased from the animal house of Shiraz University of Medical Sciences (Shiraz, Iran). The rats were kept at room temperature $\left(25 \pm 2{ }^{\circ} \mathrm{C}\right)$, controlled laboratory and natural conditions (lighting: $12 \mathrm{~h} / 12 \mathrm{~h}$, humidity: $50-55 \%$ ), with ad libitum access to standard rodent diet and water. Rates were divided after a 14-day acclimatization period into four groups $(n=8)$. The treatment groups were as follows: Control group: received corn oil $(0.5 \mathrm{~mL})$ by gastric gavage for a period of $15 \mathrm{~d}$. Groups MAL50, MAL100, and MAL200 received 50, 100, and 200 $\mathrm{mg} / \mathrm{kg}$ bw MAL (dissolved in corn oil), respectively, by gastric gavage for $15 \mathrm{~d}$ (Coban et al. 2015). Malathion dosages were equivalent to $1 / 40,1 / 20$, and $1 / 10 L D_{50}$, respectively. In this study, the standard guidelines for the use and care of laboratory animals were followed and approved by the Animal Care and Use Committee at Fasa University of medical science (Iran).

\subsection{Samples preparation}

At the end of the 15th day, all rats were anesthetized using ether and blood samples from each group were collected directly from the heart. Then, serum was prepared by centrifugation ( $3000 \times \mathrm{g}$ for $15 \mathrm{~min}$ ) and frozen at $-20^{\circ} \mathrm{C}$ until the time of analysis. Lung, testis, kidney, liver and heart samples were removed and washed immediately with ice cold $0.9 \% \mathrm{NaCl}$. The left lung, kidney, testis, left liver lobe and apex of heart were immediately transferred at $-80^{\circ} \mathrm{C}$ until the biochemical analysis to measure antioxidant, and cytokines levels. The right lung, testis, kidney, right liver lobe and base of heart were immersed in neutral buffered formalin for $24 \mathrm{~h}$.

\subsection{Histopathological study}

Fixed tissues were processed routinely and stained with hematoxylin and eosin (H\&E) according to standard instructions. The slides were evaluated using a light microscope (Olympus BX51; Olympus, Tokyo, Japan) attached to the camera (Olympus E-330, Olympus Optical Co., Ltd., Japan).

\subsection{Biochemical analysis}

All tissue samples were homogenized using RIPA buffer in a mini grinder homogenizer and subjected for biochemical analysis. Supernatants were obtained after centrifugation $\left(3000 \mathrm{rpm}, 10 \mathrm{~min}\right.$ at $\left.4{ }^{\circ} \mathrm{C}\right)$ and analyzed for MDA, CAT, SOD, IL-1 $\beta$, and TNF-a. The time-tested colorimetric assay (Bradford protein assay) was used to measure the concentration of total protein in all sample. (Bradford 1976). CAT activity was measured as previously described by Aebi, (1984), based on the reduction of hydrogen 
peroxide at $570 \mathrm{~nm}$. The activity of SOD was assayed according to Marklund method (Marklund et al. 1974) by evaluating the pyrogallol illumination and auto oxidation at $440 \mathrm{~nm}$ for $3 \mathrm{~min}$. CAT and SOD activity expressed as $\mathrm{U} / \mathrm{mg}$ protein. The thiobarbituric acid (TBA) test was used to evaluate the MDA content as described by Ohkawa et al. (Ohkawa et al. 1979). The level of MDA was measured at $535 \mathrm{~nm}$ and defined as $\mathrm{nm} / \mathrm{mg}$ protein.

The contents of IL-1ß and TNF-a was measured by commercial kits (Karmania Pars Gene Company Kerman, Iran) fallowing to the manufacturer's instructions. The ELISA plates were coated with antibodies specific for IL-1ß and TNF-a. Evaluation of these cytokines were performed as follows: In summary, the supernatant obtained from the homogenized samples was added to the wells of ELISA plates and incubated at room temperature (RT) on a shaker at $200 \mathrm{rpm}$. After washing, anti-cytokine antibody (AntiAvidin-HRP) was added and incubated at room temperature (RT) on a shaker at $200 \mathrm{rpm}$. After washing, substrate $\left(\mathrm{TMB}+\mathrm{H}_{2} \mathrm{O}_{2}\right)$ was added to each well and dark incubated at $\mathrm{RT}$. In the last step, stop solution $\left(\mathrm{H}_{2} \mathrm{SO}_{4} 1 \mathrm{~N}\right)$ was added to wells and $\mathrm{OD}$ was assayed at $450 \mathrm{~nm}$.

\subsection{Statistical analysis}

Statistical analysis of data (inflammatory mediators and oxidative stress parameters) was performed using one-way ANOVA and SPSS version 25.0. Significance differences $(p<0.05)$ between the means followed by Tukey's multiple comparison tests.

\section{Results}

\subsection{Antioxidant enzyme activity}

CAT and SOD activity were used as an indicator of oxidative stress. CAT and SOD activities are shown in Tables 1 and 2. The results indicate that CAT activity in MAL-treated rats was significantly increased in all tissues $($ Liver $=2.04 \pm 0.05 \mathrm{U} / \mathrm{mg}$ protein, Kidney $=2.35 \pm 0.15 \mathrm{U} / \mathrm{mg}$ protein, Lung $=1.96 \pm 0.03 \mathrm{U} / \mathrm{mg}$ protein, Heart $=2.52 \pm .12 \mathrm{U} / \mathrm{mg}$ protein, Testis $=1.76 \pm 0.03 \mathrm{U} / \mathrm{mg}$ protein, Blood $=96.91 \pm 6.38 \mathrm{U} / \mathrm{mg}$ protein, $p<0.05$ ). SOD activity in MAL-treated rats (Table 2 ) was significantly increased in all tissues except lung and testis (Liver $=181.25 \pm 10.42 \mathrm{U} / \mathrm{mg}$ protein, Kidney $=175.33 \pm 10.49 \mathrm{U} / \mathrm{mg}$ protein, Heart $=199.57 \pm 10.93 \mathrm{U} / \mathrm{mg}$ protein, Blood $=74.42 \pm 0.18 \mathrm{U} / \mathrm{mg}$ protein, $\mathrm{p}<0.05)$. MAL50 significantly reduced SOD activity in the lung tissue $p<0.05$. 
Table 1

Effects of oral administration of MAL (50, 100 and $200 \mathrm{mg} / \mathrm{kg}, \mathrm{b} . \mathrm{w})$ on CAT activity (U/mg pro) in the rat tissues

\section{Tissues}

\begin{tabular}{|c|c|c|c|c|c|c|}
\hline & Liver & kidney & Lung & Heart & Testis & Blood \\
\hline Control & $\begin{array}{l}0.83 \pm \\
0.03^{a}\end{array}$ & $\begin{array}{l}1.14 \pm \\
0.00^{\mathrm{a}}\end{array}$ & $1.15 \pm 0.00^{\mathrm{a}}$ & $\begin{array}{l}1.38 \pm \\
0.03^{a}\end{array}$ & $\begin{array}{l}1.21 \pm \\
0.04^{\mathrm{a}}\end{array}$ & $77.82 \pm 4.56 a$ \\
\hline MAL50 & $\begin{array}{l}1.51 \pm \\
0.06^{\mathrm{b}}\end{array}$ & $1.63 \pm 0.1^{\mathrm{a}}$ & $1.62 \pm 0.09^{b}$ & $1.5 \pm 0.03^{a}$ & $\begin{array}{l}1.57 \pm \\
0.03^{b}\end{array}$ & $\begin{array}{l}78.29 \pm \\
10.01 \mathrm{a}\end{array}$ \\
\hline MAL100 & $\begin{array}{l}1.55 \pm \\
0.05^{b}\end{array}$ & $\begin{array}{l}1.58 \pm \\
0.11^{\mathrm{a}}\end{array}$ & $\begin{array}{l}1.83 \pm \\
0.07^{b c}\end{array}$ & $2.29 \pm .14^{\mathrm{b}}$ & $1.78 \pm 0.1^{\mathrm{b}}$ & $96.91 \pm 6.38^{b}$ \\
\hline MAL200 & $\begin{array}{l}2.04 \pm \\
0.05^{c}\end{array}$ & $\begin{array}{l}2.35 \pm \\
0.15^{b}\end{array}$ & $1.96 \pm 0.03^{c}$ & $2.52 \pm .12^{b}$ & $\begin{array}{l}1.76 \pm \\
0.03^{b}\end{array}$ & $77.54 \pm 0.83 a$ \\
\hline
\end{tabular}

Table 2

Effects of oral administration of MAL (50, 100 and $200 \mathrm{mg} / \mathrm{kg}$, b.w) on SOD activity (U/mg pro) in the rat tissues

\begin{tabular}{|c|c|c|c|c|c|c|}
\hline & & & Tissues & & & \\
\hline & Liver & kidney & Lung & Heart & Testis & Blood \\
\hline Control & $\begin{array}{l}106.22 \pm \\
2.38^{a}\end{array}$ & $\begin{array}{l}129.04 \pm \\
9.77^{a}\end{array}$ & $\begin{array}{l}171.39 \pm \\
5.43^{b}\end{array}$ & $\begin{array}{l}123.79 \pm \\
2.21^{\mathrm{a}}\end{array}$ & $\begin{array}{l}137.06 \pm \\
2.17\end{array}$ & $\begin{array}{l}41.82 \pm \\
0.31^{a}\end{array}$ \\
\hline MAL50 & $\begin{array}{l}141.03 \pm \\
3.02^{b}\end{array}$ & $97.9 \pm 6.90^{\mathrm{a}}$ & $\begin{array}{l}138.27 \pm \\
3.56^{\mathrm{a}}\end{array}$ & $\begin{array}{l}126.06 \pm \\
1.88^{\mathrm{a}}\end{array}$ & $\begin{array}{l}141.06 \pm \\
0.79\end{array}$ & $\begin{array}{l}74.16 \pm \\
1.42^{\mathrm{b}}\end{array}$ \\
\hline MAL100 & $\begin{array}{l}175.98 \pm \\
6.28^{c}\end{array}$ & $\begin{array}{l}107.87 \pm \\
4.36^{\mathrm{a}}\end{array}$ & $\begin{array}{l}177.22 \pm \\
4.64^{b}\end{array}$ & $\begin{array}{l}159.69 \pm \\
4.15^{b}\end{array}$ & $\begin{array}{l}135.55 \pm \\
1.17\end{array}$ & $\begin{array}{l}76.32 \pm \\
0.58^{b}\end{array}$ \\
\hline MAL200 & $\begin{array}{l}181.25 \pm \\
10.42^{c}\end{array}$ & $\begin{array}{l}175.33 \pm \\
10.49^{b}\end{array}$ & $\begin{array}{l}163.633 \pm \\
3.63^{\mathrm{b}}\end{array}$ & $\begin{array}{l}199.57 \pm \\
10.93^{\mathrm{C}}\end{array}$ & $\begin{array}{l}142.21 \pm \\
1.18\end{array}$ & $\begin{array}{l}74.42 \pm \\
0.18^{b}\end{array}$ \\
\hline
\end{tabular}

\subsection{Lipid peroxidation marker (MDA level)}

MDA is one of the end-product generated by peroxidation of polyunsaturated fatty acids and commonly known as a marker of oxidative stress. MAL-treated rats showed higher MDA levels in the, liver, kidney, lung, and heart tissues when compared with the control group (Liver $=6.37 \pm 0.11 \mathrm{nmol} / \mathrm{mg}$ protein, 
Kidney $=5.6 \pm 0.33 \mathrm{nmol} / \mathrm{mg}$ protein, Lung $=6.61 \pm 0.21 \mathrm{nmol} / \mathrm{mg}$ protein, Heart $=5.28 \pm 0.25 \mathrm{nmol} / \mathrm{mg}$ protein, $\mathrm{p}<0.05)($ Table 3$)$.

Table 3

Effects of oral administration of MAL (50, 100 and $200 \mathrm{mg} / \mathrm{kg}$, b.w) on MDA activity (nmol/mg pro) in the rat tissues

\begin{tabular}{|lllllll|}
\hline \multicolumn{7}{c|}{ Tissues } \\
\hline & Liver & kidney & Lung & Heart & Testis & Blood \\
\hline Control & $4.03 \pm 0.44^{\mathrm{a}}$ & $3.43 \pm 0.3^{\mathrm{a}}$ & $4.26 \pm 0.1^{\mathrm{a}}$ & $3.49 \pm 0.21^{\mathrm{a}}$ & $6.79 \pm 0.43$ & $1.61 \pm 0.48$ \\
\hline MAL50 & $7.54 \pm 0.11^{\mathrm{b}}$ & $4.39 \pm 0.15^{\mathrm{ab}}$ & $7.67 \pm 0.73^{\mathrm{b}}$ & $5.5 \pm 0.33^{\mathrm{c}}$ & $7.99 \pm 0.53$ & $1.95 \pm 0.19$ \\
\hline MAL100 & $6.76 \pm 0.37^{\mathrm{b}}$ & $6.92 \pm 0.73^{\mathrm{c}}$ & $7.00 \pm 0.58^{\mathrm{b}}$ & $4.48 \pm 0.15^{\mathrm{b}}$ & $7.18 \pm 0.55$ & $1.37 \pm 0.07$ \\
\hline MAL200 & $6.37 \pm 0.11^{\mathrm{b}}$ & $5.6 \pm 0.33^{\mathrm{bc}}$ & $6.61 \pm 0.21^{\mathrm{b}}$ & $5.28 \pm 0.25^{\mathrm{bc}}$ & $6.91 \pm 0.6$ & $1.74 \pm 0.25$ \\
\hline $\begin{array}{l}\text { Data were expressed as mean } \pm \text { SE }(\mathrm{n}=8) \text {, Different superscript letters }(\mathrm{a}, \mathrm{b}, \text { and } \mathrm{c}) \text { indicate a } \\
\text { significant difference }(\mathrm{P}<0.05) \text { among groups (column). }\end{array}$ & & & \\
\hline
\end{tabular}

\subsection{Pro-inflammatory cytokines (IL-1 $\beta$ and TNF-a)}

The pro-inflammatory cytokine, IL-1 $\beta$, content in the kidney (MAL50 $=448.91 \pm 10.69$ and MAL100 $=$ $525.02 \pm 35 \mathrm{pg} / \mathrm{mg}$ protein), lung (only MAL50 $=434.73 \pm 35.05 \mathrm{pg} / \mathrm{mg}$ protein), and testis (MAL50, 100, and $200=464.35 \pm 18.84,415.45 \pm 20.52,400.34 \pm 6.71$, respectively) was significantly higher when compared to untrained rats (Table 4). MAL200-treated rats showed higher IL-1 $\beta$ levels in the liver (362.78 $\pm 13.35 \mathrm{pg} / \mathrm{mg}$ protein), Kidney (314.96 $\pm 21.99 \mathrm{pg} / \mathrm{mg}$ protein), heart (250.9 $\pm 7.77 \mathrm{pg} / \mathrm{mg}$ protein), and blood tissues (52.28 $\pm 7.42 \mathrm{pg} / \mathrm{mg}$ protein) (Table 4$)$. 
Table 4

Effects of oral administration of MAL (50, 100 and $200 \mathrm{mg} / \mathrm{kg}$, b.w) on IL-1 $1 \beta$ contents (pg/mg pro) in the rat tissues

\section{Tissues}

\begin{tabular}{lllllll} 
& Liver & kidney & Lung & Heart & Testis & Blood \\
Control & $445.73 \pm$ & $346.16 \pm$ & $310.23 \pm$ & $359.06 \pm$ & $255.2 \pm$ & $72.42 \pm$ \\
& $20.12^{\mathrm{c}}$ & $14.59^{\mathrm{ab}}$ & $13.33^{\mathrm{a}}$ & $7.77^{\mathrm{bc}}$ & $18.17^{\mathrm{a}}$ & $8.38^{\mathrm{a}}$ \\
\hline MAL50 & $436.01 \pm$ & $448.91 \pm$ & $434.73 \pm$ & $431.37 \pm$ & $464.35 \pm$ & $59.34 \pm$ \\
& $19.36^{\mathrm{bc}}$ & $10.69^{\mathrm{bc}}$ & $35.05^{\mathrm{b}}$ & $21.46^{\mathrm{c}}$ & $18.84^{\mathrm{b}}$ & $4.5^{\mathrm{ab}}$ \\
\hline MAL100 & $350.45 \pm$ & $525.02 \pm$ & $330.7 \pm$ & $293.06 \pm$ & $415.45 \pm$ & $50.79 \pm$ \\
& $19.5^{\mathrm{a}}$ & $35.6^{\mathrm{c}}$ & $19.97^{\mathrm{ab}}$ & $21.31^{\mathrm{ab}}$ & $20.52^{\mathrm{b}}$ & $6.35^{\mathrm{b}}$ \\
\hline MAL200 & $362.78 \pm$ & $314.96 \pm$ & $316.38 \pm$ & $250.9 \pm$ & $400.34 \pm$ & $52.28 \pm$ \\
& $13.35^{\mathrm{ab}}$ & $21.99^{\mathrm{a}}$ & $30.3^{\mathrm{a}}$ & $7.77^{\mathrm{a}}$ & $6.71^{\mathrm{b}}$ & $7.42^{\mathrm{b}}$
\end{tabular}

Data were expressed as mean $\pm S E(n=8)$, Different superscript letters $(a, b$, and $c)$ indicate a significant difference $(P<0.05)$ among groups (column).

TNF-a content ( $\mathrm{pg} / \mathrm{mg}$ pro) in the rat tissues is shown in Table 5. The results indicate that MAL200 significantly attenuated TNF-a content in all tissues expect of the lung and testis (Liver $=394.03 \pm 11.8$ $\mathrm{pg} / \mathrm{mg}$ protein, Kidney $=328.63 \pm 15.34 \mathrm{pg} / \mathrm{mg}$ protein, Heart $=253.23 \pm 17.27 \mathrm{pg} / \mathrm{mg}$ protein, Blood $=$ $72.62 \pm 9.62 \mathrm{pg} / \mathrm{mg}$ protein, $\mathrm{p}<0.05)$.

Table 5

Effects of oral administration of MAL (50, 100 and $200 \mathrm{mg} / \mathrm{kg}$, b.w) on TNF-a contents ( $\mathrm{pg} / \mathrm{mg}$ pro) in the rat tissues

\section{Tissues}

\begin{tabular}{|lllllll|} 
& Liver & kidney & Lung & Heart & Testis & Blood \\
\hline Control & $448.77 \pm$ & $447.23 \pm$ & $370.67 \pm$ & $352.05 \pm$ & $352.5 \pm$ & $100.82 \pm$ \\
& $11.06^{\mathrm{c}}$ & $19.53^{\mathrm{c}}$ & 14.25 & $13.43^{\mathrm{a}}$ & 18.77 & $15.91^{\mathrm{a}}$ \\
\multirow{2}{*}{ MAL50 } & $351.03 \pm$ & $366.24 \pm$ & $351.82 \pm$ & $374.6 \pm$ & $345.68 \pm$ & $73.91 \pm$ \\
& $12.23^{\mathrm{ab}}$ & $6.04^{\mathrm{ab}}$ & 24.95 & $18.53^{\mathrm{a}}$ & 41.18 & $7.44^{\mathrm{ab}}$ \\
\multirow{2}{*}{ MAL100 } & $315.97 \pm$ & $412.49 \pm$ & $344.24 \pm$ & $337.28 \pm$ & $328.95 \pm$ & $92.03 \pm$ \\
& $12.78^{\mathrm{a}}$ & $9.27^{\mathrm{bc}}$ & 60.94 & $26^{\mathrm{ab}}$ & 21.29 & $7.42^{\mathrm{ab}}$ \\
\multirow{2}{*}{ MAL200 } & $394.03 \pm$ & $328.63 \pm$ & $349.70 \pm$ & $253.23 \pm$ & $299.49 \pm$ & $72.62 \pm$ \\
& $11.8^{\mathrm{b}}$ & $15.34^{\mathrm{a}}$ & 5.12 & $17.27^{\mathrm{b}}$ & 11.74 & $9.62^{\mathrm{b}}$ \\
\hline
\end{tabular}

Data were expressed as mean $\pm S E(n=8)$, Different superscript letters $(a, b$, and $c)$ indicate a significant difference $(P<0.05)$ among groups (column). 
All H\&E-stained liver, testes, kidney, heart and lung sections from different experimental groups were evaluated histologically. The histopathological micrographs of normal tissues have been shown in figures (ctrl). Micrographs of liver sections of MAL (100-200 mg/kg) post-treatment showed severe fatty change and hydropic degeneration of hepatocytes (Fig. 1). Moreover, portal hepatitis and infiltration of polymorphonuclear inflammatory cells were evident in the highest dose of MAL $(200 \mathrm{mg} / \mathrm{kg})$. The histopathological evaluation of the kidney which was exposed to the highest dose of MAL $(200 \mathrm{mg} / \mathrm{kg})$ showed moderate proximal and distal tubular cell necrosis and the classical architecture of the kidney has deteriorated. Moreover, tubular cast formation was also seen in this treatment group as shown in (Fig. 2). The cardiac samples of treatment groups with Malathion (100-200 mg/kg) were shown cardiac myocyte necrosis (in both doses) and severe hyperemia (only in $200 \mathrm{mg} / \mathrm{kg}$ ) (Fig. 3). Also, these results showed that the toxicity of these agents was increased in a dose-dependent manner. In all treatment groups, histopathological evaluation of testes and lung showed the normal tissue without significant histopathological changes (data not shown).

\section{Discussion}

In this study, we investigated antioxidant enzyme activity (SOD, CAT), MDA level, and expression of TNFalpha, and IL- $\beta$ in MAL-treated rats. Our funding showed that SOD (liver, kidney, heart, and blood tissues), and CAT activity (all tissues), MDA level (liver, kidney, lung, and heart) in the MAL-treated rats was significantly higher than that compared with the control group.

Organophosphate agents like MAL plays a direct toxic role in antioxidant defense systems and lipid peroxidation (Brocardo et al. 2007). Furthermore, emerging evidence suggests that MAL can increase generation of reactive oxygen species (ROS), and following that oxidative stress in biological system (Fortunato et al. 2006). Acute and chronic use of MAL, as noted by Fortunato et al, results in induce oxidative stress and antioxidant enzymes activity such as SOD and CAT in rat brain regions (Fortunato et al. 2006). Results from this study suggest that MAL induced oxidative stress resulted in an increased in the activity of CAT and MDA. This evidence is consistent with the results obtained by Edwards et al. that showed MAL increases levels of MDA through oxidative stress in human liver carcinoma cells(Edwards et al. 2013). It was also demonstrated, other organophosphates such as diazinon, can increase MDA level in the testis tissue of male rats (Anbarkeh et al. 2014). It has also been reported that MAL increased the levels of MDA and decreased SOD and CAT activities (Durak et al. 2009). Similar to our results, Akhgar et al, reported a significant increase CAT and SOD activity in liver and blood cell, but we used lower doses of MAL (Akhgari et al. 2003). Possamai et al. demonstrated that intraperitoneal administration of subchronic MAL increased liver CAT activity only at lower doses. The administration method and doses of MAL are the most important differences between Possamai et al. study and our research (Possamai et al. 2007). The results of our study showed significant increase in SOD level in the liver, kidney, heart, and blood and significant decrease in SOD level in the lung (MAL50). Previous studies indicated that MAL increased or decreased activities of SOD; changes in enzyme levels might differ depending on tissue and duration of exposure (Yarsan et al. 1999; Ahmed et al. 2000). 
Our results revealed that MAL-treatment induced a significant increase in the level of IL- $\beta$ in the testis, kidney, and lung tissues, while blood, liver, kidney, and heart IL- $\beta$ level reduced. Experimental studies proved that sub-chronic MAL-induced tissue damage resulted in stimulate inflammatory cytokines releasing in hepatocytes, such as IL-1 $\beta$ (Badr 2020). Moreover, Ince et al.(2017) reported an increased IL-1 beta expression MAL-induced toxicity rat model. In contrast, a significant decrease in blood level of IL-1 beta expression was observed in rats that acute intoxication with MAL, which is similar to our results (Zabrodskii et al. 2015). In addition to the liver, herein, we reported an increased IL-1 beta expression in other tissues such as the kidneys, testes, and lungs in rats treated with MAL.

In our study, MAL caused a significant decreases in the TNF level in the liver, kidney, heart, and blood tissues. TNF- $\alpha$ is one of the most cytokines involved in host innate and adaptive immune response, tissue injury, cell proliferation, programmed cell death (apoptosis), etc. (Pober et al. 2006). Toxicity and biological effects of MAL have been reported in several studies suggesting that their effects may be related to the increasing of pro-inflammatory molecules like TNF-a. Many studies have shown, contrary to our results that OPs induce inflammatory reactions and increase cytokines release. For example, neurobehavioral impairments in rat's exposure to MAL have been reported as a consequence of the evaluation of TNF-a (Mohammadzadeh et al. 2018). According to the literature, TNF- $\alpha$ and IL-1 $\beta$ can induced apoptosis signaling pathways in organophosphate treated microglial cells (Tan et al. 2013). Furthermore, it has been reported that acute organophosphorus pesticide poisoning (diazinon) can evaluate expression of TNF-a in mice liver and spleen (Hariri et al. 2010). As well as Tian et al. (2015) indicated that the expression of pro-inflammatory cytokines, IL- 6 and TNF-a, increased in the amygdala of sub-acute chlorpyrifos -treated rats after 24 and 72 hours (Tian et al. 2015). On the other hand, Ayub et al, 2003 showed that MAL can suppression nitrite production and TNF-a generation in LPS-induced cells (Ayub et al. 2003). There are other reports that show the effect of organophosphorus toxins on the reduction of cytokines. For example, according to our results, Moser et.al. (2015) reported that overstimulation of muscarinic and/or nicotinic receptors in immune cells by acetylcholine inhibitor pesticides in high doses reduce the secretion of inflammatory cytokines (Moser et al. 2015). Alluwaimi and Hussein (2007) showed that there are similar conclusions in terms of reduction of inflammatory cytokines by diazinone (1/5 LD50).

\section{Conclusion}

Thus, in summary, our results indicate that even short-term toxicity of MAL increased antioxidant enzymes activity (SOD and CAT), and lipid peroxidation (MDA level) synchronously in many tissues of rats. The potency of MAL-induced tissue damage was also observed with cell degeneration, hyperemia, hemorrhage, inflammation, and cell necrosis in different tissues in a short time. Testes are probably less sensitive to the ratio of malathion-induced oxidative stress. Moreover, the suppression effect of MAL on inflammatory cytokines was demonstrated in this study, which suggests further studies are needed to evaluate the different doses and duration time on inflammatory responses. 


\section{Declarations}

\section{Conflict of interest}

There is no conflict of interest amongst the authors.

\section{Ethical Approval and Consent to Participate}

Not applicable

\section{Consent to Publish}

Not applicable

\section{Authors Contributions}

All authors contributed to the study concept and design. Supervision, data curation and writing-review and editing: Mehran Sayadi; Formal analysis, data curation and writing original draft: Mohammad Kiani and Seyed Mohammad Mazloomi; Methodology and project administration: Hiva Alipanah, Roghayeh Nejati and Amene Nematollahi. All authors read and approved the final manuscript.

\section{Funding}

This study was supported by Fasa University of Medical Sciences, grant No. 97459. Moreover, it has been ethically approved, IR.FUMS.REC.1398.177.

\section{Competing Interests}

No researchers have competing interest in this study.

\section{Availability of data and materials}

The datasets used and/or analyzed during the current study are available from the corresponding author on reasonable request.

\section{References}

Aebi, H. (1984) Catalase in vitro. Meth Enzymol 105: 121-126. https://doi.org/10.1016/S00766879(84)05016-3

Ahmed, R. S., V. Seth, S. Pasha and B. Banerjee (2000) Influence of dietary ginger (Zingiber officinales Rosc) on oxidative stress induced by malathion in rats. Food Chem Toxicol 38(5): 443-450. https://doi.org/10.1016/S0278-6915(00)00019-3

Akhgari, M., M. Abdollahi, A. Kebryaeezadeh, R. Hosseini and O. Sabzevari (2003) Biochemical evidence for free radicalinduced lipid peroxidation as a mechanism for subchronic toxicity of malathion in blood 
and liver of rats. Hum Exp Toxicol 22(4): 205-211. https://doi.org/10.1191/0960327103ht346oa

Alluwaimi, A. M. and Y. Hussein (2007) Diazinon immunotoxicity in mice: modulation of cytokines level and their gene expression. Toxicol 236(1-2): 123-131. https://doi.org/10.1016/j.tox.2007.04.004

Anbarkeh, F. R., M. R. Nikravesh, M. Jalali, H. R. Sadeghnia, Z. Sargazi and L. Mohammdzadeh (2014) Single dose effect of diazinon on biochemical parameters in testis tissue of adult rats and the protective effect of vitamin E. Iran J Reprod Med 12(11): 731.

Ayub, S., J. Verma and N. Das (2003) Effect of endosulfan and malathion on lipid peroxidation, nitrite and TNF-a release by rat peritoneal macrophages. Int. Immunopharmacol 3(13-14): 1819-1828. https://doi.org/10.1016/j.intimp.2003.08.006

Badr, A. M. (2020) Organophosphate toxicity: updates of malathion potential toxic effects in mammals and potential treatments. Environ Sci Pollut Res Int 27: 26036-26057. https://doi.org/10.1007/s11356020-08937-4

Bradford, M. M. (1976) A rapid and sensitive method for the quantitation of microgram quantities of protein utilizing the principle of protein-dye binding. Anal Biochem 72(1-2): 248-254. https://doi.org/10.1016/0003-2697(76)90527-3

Brocardo, P. S., F. Assini, J. L. Franco, P. Pandolfo, Y. M. Müller, R. N. Takahashi, A. L. Dafre and A. L. S. Rodrigues (2007) Zinc attenuates malathion-induced depressant-like behavior and confers neuroprotection in the rat brain. Toxicol Sci 97(1): 140-148. https://doi.org/10.1093/toxsci/kfm024

Coban, F. K., S. Ince, I. Kucukkurt, H. H. Demirel and O. Hazman (2015) Boron attenuates malathioninduced oxidative stress and acetylcholinesterase inhibition in rats. Drug Chem Toxicol 38(4): 391-399. https://doi.org/10.3109/01480545.2014.974109

Durak, D., F. G. Uzun, S. Kalender, A. Ogutcu, M. Uzunhisarcikli and Y. Kalender (2009) Malathion-induced oxidative stress in human erythrocytes and the protective effect of vitamins $\mathrm{C}$ and $\mathrm{E}$ in vitro. Environ Toxicol 24(3): 235-242. https://doi.org/10.1002/tox.20423

Eddleston, M., N. A. Buckley, P. Eyer and A. H. Dawson (2008) Management of acute organophosphorus pesticide poisoning. Lancet 371(9612): 597-607. https://doi.org/10.1016/S0140-6736(07)61202-1

Edwards, F. L., C. G. Yedjou and P. B. Tchounwou (2013) Involvement of oxidative stress in methyl parathion and parathion-induced toxicity and genotoxicity to human liver carcinoma (HepG2) cells. Environ Toxicol 28(6): 342-348. https://doi.org/10.1002/tox.20725

Flehi-Slim, I., I. Chargui, S. Boughattas, A. El Mabrouk, Y. Belaïd-Nouira, F. Neffati, M. F. Najjar, Z. Haouas and H. B. Cheikh (2015) Malathion-induced hepatotoxicity in male Wistar rats: biochemical and histopathological studies. Environ Sci Pollut Res 22(22): 17828-17838. https://doi.org/10.1007/s11356015-5014-5 
Fortunato, J. J., G. Feier, A. M. Vitali, F. C. Petronilho, F. Dal-Pizzol and J. Quevedo (2006) Malathioninduced oxidative stress in rat brain regions. Neurochem Res 31(5): 671-678.

https://doi.org/10.1007/s11064-006-9065-3

Gupta, V. K., N. J. Siddiqi, A. K. Ojha and B. Sharma (2019) Hepatoprotective effect of Aloe vera against cartap-and malathion-induced toxicity in Wistar rats. J Cell Physiol 234(10): 18329-18343.

https://doi.org/10.1002/jcp.28466

Hariri, A. T., S. A. Moallem, M. Mahmoudi, B. Memar and H. Hosseinzadeh (2010) Sub-acute effects of diazinon on biochemical indices and specific biomarkers in rats: protective effects of crocin and safranal. Food Chem Toxicol 48(10): 2803-2808. https://doi.org/10.1016/j.fct.2010.07.010

Heshmati, A., A. Nili-Ahmadabadi, A. Rahimi, A. Vahidinia and M. Taheri (2020) Dissipation behavior and risk assessment of fungicide and insecticide residues in grape under open-field, storage and washing conditions. J Clean Prod 270: 122287. https://doi.org/10.1016/j.jclepro.2020.122287

Ince, S., D. Arslan-Acaroz, H. H. Demirel, N. Varol, H. A. Ozyurek, F. Zemheri and I. Kucukkurt (2017) Taurine alleviates malathion induced lipid peroxidation, oxidative stress, and proinflammatory cytokine gene expressions in rats. Biomed Pharmacother 96: 263-268. https://doi.org/10.1016/j.biopha.2017.09.141

Jalili, C., M. H. Farzaei, S. Roshankhah and M. R. Salahshoor (2019) Resveratrol attenuates malathioninduced liver damage by reducing oxidative stress. J Lab Physicians 11(03): 212-219. https://doi.org/10.4103/JLP.JLP_43_19

Lasram, M. M., A. B. Annabi, N. El Elj, S. Selmi, A. Kamoun, S. El-Fazaa and N. Gharbi (2009) Metabolic disorders of acute exposure to malathion in adult Wistar rats. J Hazard Mater 163(2-3): 1052-1055. https://doi.org/10.1016/j.jhazmat.2008.07.059

Marklund, S. and G. Marklund (1974) Involvement of the superoxide anion radical in the autoxidation of pyrogallol and a convenient assay for superoxide dismutase. Europ J Biochem 47(3): 469-474. https://doi.org/10.1111/j.1432-1033.1974.tb03714.x

Mohammadzadeh, L., H. Hosseinzadeh, K. Abnous and B. M. Razavi (2018) Neuroprotective potential of crocin against malathion-induced motor deficit and neurochemical alterations in rats. Environ Sci Pollut Res 25(5): 4904-4914. https://doi.org/10.1007/s11356-017-0842-0

Moser, V. C., N. Stewart, D. L. Freeborn, J. Crooks, D. K. MacMillan, J. M. Hedge, C. E. Wood, R. L. McMahen, M. J. Strynar and D. W. Herr (2015) Assessment of serum biomarkers in rats after exposure to pesticides of different chemical classes. Toxicol appl pharmacol 282(2): 161-174. https://doi.org/10.1016/j.taap.2014.11.016

Mostafalou, S., M. A. Eghbal, A. Nili-Ahmadabadi, M. Baeeri and M. Abdollahi (2012) Biochemical evidence on the potential role of organophosphates in hepatic glucose metabolism toward insulin 
resistance through inflammatory signaling and free radical pathways. Toxicol Ind Health 28(9): 840-851. https://doi.org/10.1177/0748233711425073

Ohkawa, H., N. Ohishi and K. Yagi (1979) Assay for lipid peroxides in animal tissues by thiobarbituric acid reaction. Anal Biochem 95(2): 351-358. https://doi.org/10.1016/0003-2697(79)90738-3

Pober, J. and W. Min (2006) Endothelial cell dysfunction, injury and death. Vascular Endothelium II: 135156. https://doi.org/10.1007/3-540-36028-X_5

Possamai, F., J. Fortunato, G. Feier, F. Agostinho, J. Quevedo, D. Wilhelm Filho and F. Dal-Pizzol (2007) Oxidative stress after acute and sub-chronic malathion intoxication in Wistar rats. Environ Toxicol Pharmacol 23(2): 198-204. https://doi.org/10.1016/j.etap.2006.09.003

Rahimi, A., A. Heshmati and A. Nili-Ahmadabadi (2021) Changes in pesticide residues in field-treated fresh grapes during raisin production by different methods of drying. Dry Technol: 22(2): 1-14.

https://doi.org/10.1080/07373937.2021.1919140

Tan, M.-S., J.-T. Yu, T. Jiang, X.-C. Zhu and L. Tan (2013) The NLRP3 inflammasome in Alzheimer's disease. Mol Neurobiol 48(3): 875-882. https://doi.org/10.1007/s12035-013-8475-x

Tian, J., H. Dai, Y. Deng, J. Zhang, Y. Li, J. Zhou, M. Zhao, M. Zhao, C. Zhang and Y. Zhang (2015) The effect of HMGB1 on sub-toxic chlorpyrifos exposure-induced neuroinflammation in amygdala of neonatal rats. Toxicol 338: 95-103. https://doi.org/10.1016/j.tox.2015.10.010

Yarsan, E., M. Tanyuksel, S. Celik and A. Aydin (1999) Effects of aldicarb and malathion on lipid peroxidation. Bull Environ Contam Toxicol 63(5): 575-581. https://doi.org/10.1007/s001289901019

Zabrodskii, P., V. Maslyakov and M. Gromov (2015) Changes in the function of lymphocytes and cytokine concentration in blood caused by the action of atropine under conditions of acute malathion intoxication. Eksperimental'naia i klinicheskaia farmakologiia 78(7): 20-23.

\section{Figures}




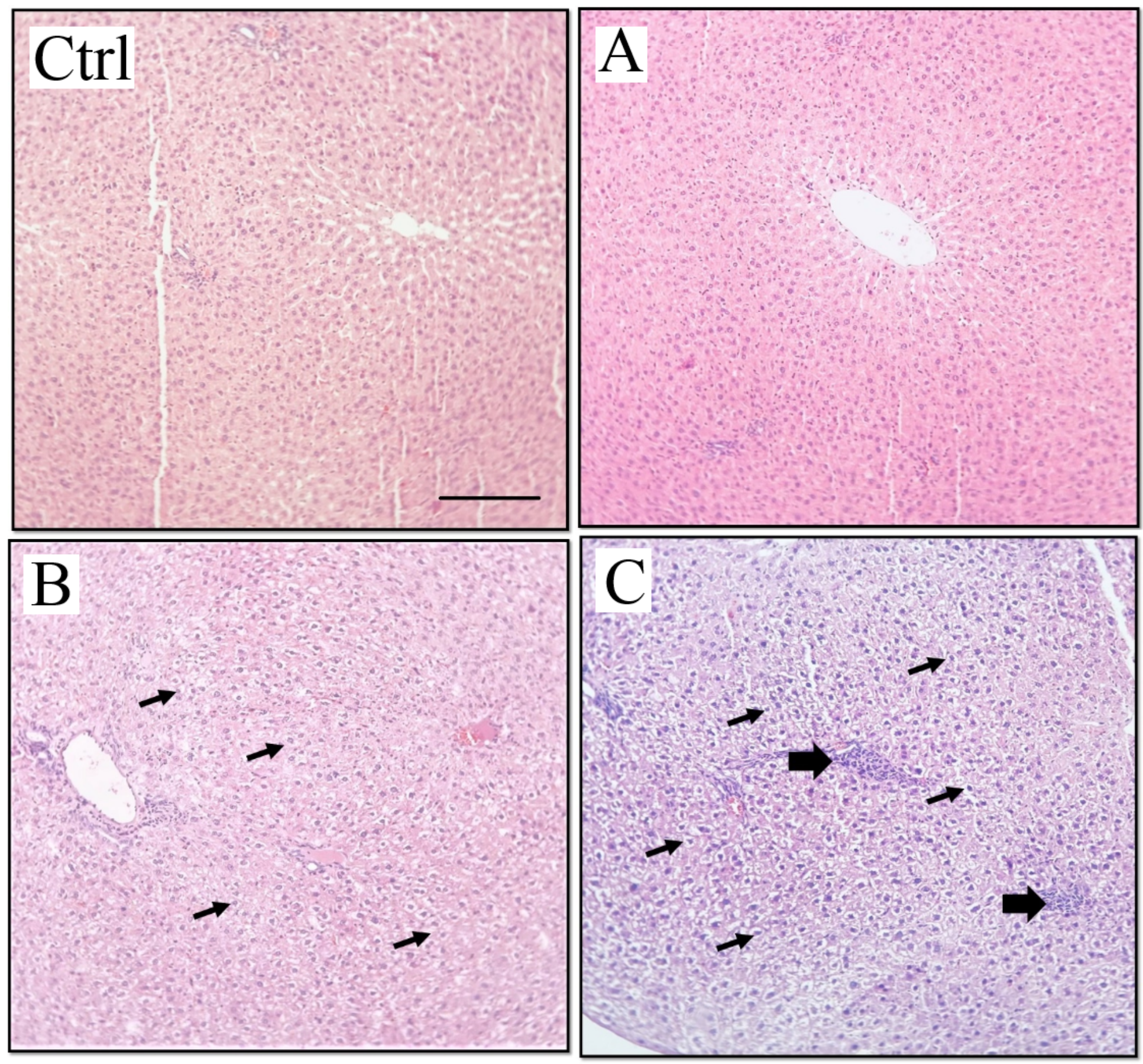

Figure 1

Light microscopy observation of rat liver. H\&E results showed vacuolar (ballooning) degeneration of hepatocytes (thin black arrows) and infiltration of inflammatory cells (Black thick arrows). (Ctrl) control; (A) MAL 50 mg/ kg, b.w; (B) MAL 100 mg/ kg, b.w; (C) MAL 200 mg/ kg, b.w , H\&E stain, 200X. Scale bar: $100 \mu \mathrm{m}$. 


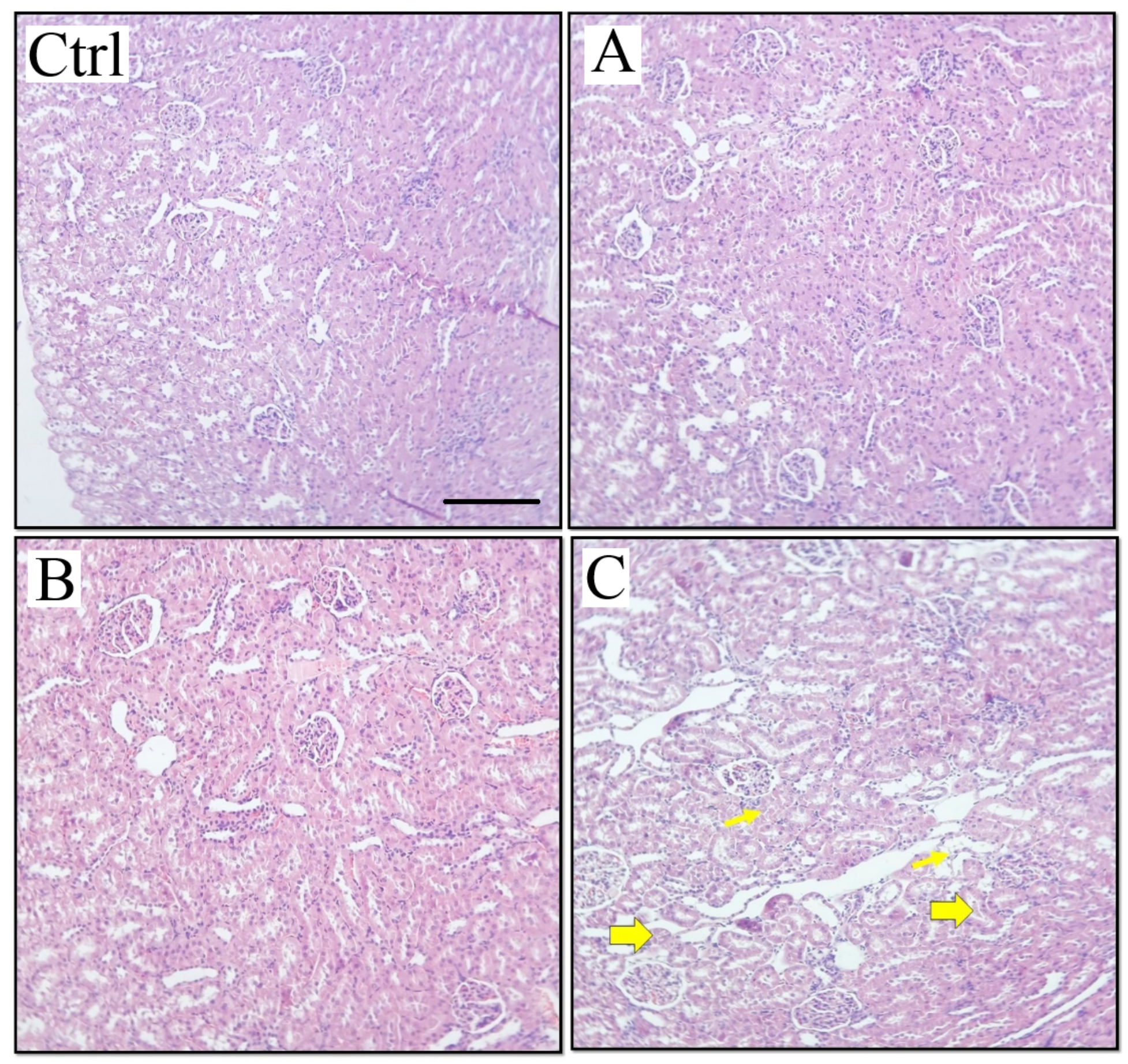

Figure 2

Light microscopy observation of the kidney. Kidney sections of MAL-treated rats showed tubular cast formation (yellow thick arrows) and tubular cell necrosis (yellow thin arrows) were observed in kidney samples of the highest dose of this treatment (13.5 mg/ kg, b.w) (C), (Ctrl) control; (A) MAL $50 \mathrm{mg} / \mathrm{kg}$, b.w; (B) MAL 100 mg/ kg, b.w; (C) MAL 200 mg/ kg, b.w , H\&E stain, 200X. Scale bar: $100 \mu \mathrm{m}$. 


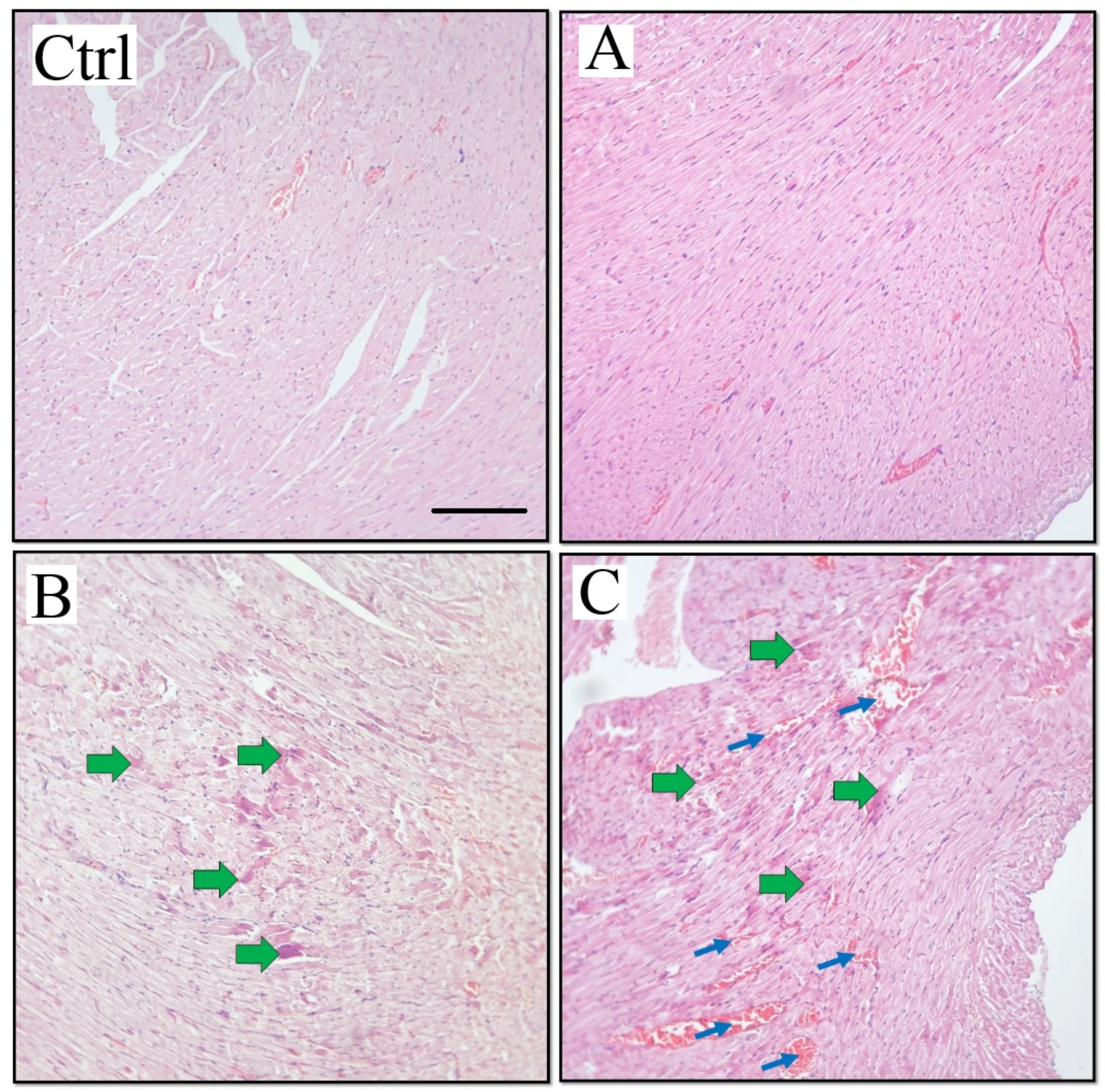

Figure 3

Light microscopy observation of rat heart. Heart sections of MAL-treated rats showed severe hyperemia and hemorrhage in group $C$ (blue arrows) and necrosis of myocardial cells in Group B \& $C$ (thick green arrows), (Ctrl) control; (A) MAL 50 mg/ kg, b.w; (B) MAL 100 mg/ kg, b.w; (C) MAL 200 mg/ kg, b.w , H\&E stain, 200X. Scale bar: $100 \mu \mathrm{m}$. 